\title{
Comparative Analysis of Export Similarity Index between China and EU
}

\author{
Pei-Zhi Wang ${ }^{1, a}$, Xiao-Jing Liü,b, \\ ${ }^{1,2}$ Shandong university of Finance and Economics, shun gen Road 40, Ji Nan City ,Shandong \\ Province, China

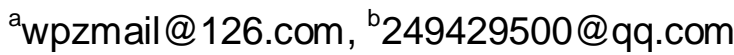 \\ ${ }^{*}$ Corresponding author
}

Keywords: China and EU, Export similarity index, Trade competitiveness.

\begin{abstract}
This paper is to do research on the export similarity between China and European Union (EU) in world market, American market and Indian market by using the export similarity index during 2007 to 2013. The empirical analysis on these indexes indicates that China and EU have a higher level of export similarity index in developed countries' market, which induces a fierce competition of export products. In the developing countries' market, they have a downward trend, which weaken their trade competitiveness and strengthen trade complementary. Based on this tendency, effective measures should be taken to strengthen inter-regional trade cooperation between China and EU and reduce the bilateral trade friction. Meanwhile, our authority need continue to push further reform of the industrial structure and enhance the competitiveness of the export products.
\end{abstract}

\section{Introduction}

\section{Background}

In recent years, the intercourse in economy and trade between EU and China is more and more frequency. The EU has become China's largest trading partner since the enlargement of EU to 25 countries in 2004. Meanwhile, China is the second largest trading partner of EU, just behind the US. The bilateral trade relationship between China and EU is increasingly important. However, the bilateral trade friction is also increasing, owing to the expansion of trade surplus of China with the EU. Only in 2007, EU launched six-time anti-dumping investigations against China, and another series of investigations in 2008 and 2009. At the same time, the European Commission refused to acknowledge China's complete market economy status twice. Various disputes have hindered further development of trade between China and EU in large part. In this context, this article tries to analyses the trade competitiveness and trade complementaries between China and EU by use of trade similarity index, in order to make valuable recommendations on the further trade development of the two partners.

\section{Literature Review}

The research about China's export similarity index in available literatures mainly focused on three aspects as following:

First, overall researches about export similarity index between China and East Asian countries. Xinpeng $\mathrm{Xu}$ and Ligang Song uses the export similarity index established in the third market to analyze the trade connection among East Asian economies and the competition effect of the economies with export similarity in the third market (Xinpeng Xu, Ligang Song 2002). Zhiyu Shi estimates the export similarity index of China and ASEAN countries on the third market outside China-ASEAN Free Trade Area, which reveals that the convergence of export structure between China and ASEAN countries is becoming more and more obvious. He concludes that the competition on bilateral export will chronicle(Zhiyu Shi 2003). Haibiao Cheng makes an experimental research on the export comparability between China and five countries of ASEAN. The result shows that there is large comparability on the whole export, industry products export and the export to US, which reflects the drastic competing relationship between China and the five 
countries of AESEAN. He concludes that an integrative system should be built to realize double-win (Haibiao Cheng 2006).

Second, focus on the export similarity index of certain industries between China and specific countries. From the angles of product and market, Lin Sun uses export similarity index to analyze agricultural trade competition degree and its trends between China, Japan and Korea. The results indicate that the trade relation between China, Japan and Korea is not mainly competition. These three countries should be cooperate in the field of agriculture to promote the product difference and reduce the competition degree(Lin Sun 2008). Guoan Wang and Wenya Wang use the export similarity index to analyze the export structure of manufactured goods between China and South Korea, which testifies that the trade relationship between the two sides is changing. In the early stage the trade relationship between the two sides is complementary, and at present is competitive(Guoan Wang, Wenya Wang 2007).

However, the numbers of papers related to the export similarity between China and EU is relatively small. Chunrong Yan and Qiuju Zhang used export similarity index to measure the trade competence and complementation between China and EU's old and new members during 1999 and 2006. The result shows that the overall trade affinity between China and EU is increasing in recent years. And the trade potential between China and EU's new members is bigger than the trade potential between China and EU's old members.

Defects of the existing studies are the following: (1) studies too much focus on the export similarity of China with east Asia, as well as developing countries and regions, lack the analyses of EU which is the import economies in the world.(2) the research data is too old to reflect the current condition, lack the latest data analysis.

This article attempts to make up the defects of the existing research by using the latest data from the United Nations to make quantitative analysis of the export similarity between China and the EU in developed countries and developing countries market. This paper aims to provide empirical basis of cooperation and development between China and EU, and then offer suggestions for further development of trade with EU.

\section{Methodology}

\section{Export Similarity Index}

Finger and Kreinin(1979) put forward the calculation formula of product similarity index which is mainly to measure the export similarity between two countries or country groups in the world market or the third market. It is defined by the formula:

$$
\mathrm{S}(\mathrm{ij}, \mathrm{k})=\left\{\sum_{\mathrm{l}} \min \left(\frac{\mathrm{x}_{\mathrm{ik}}^{\mathrm{l}}}{\mathrm{X}_{\mathrm{ik}}}, \frac{\mathrm{x}_{\mathrm{jk}}^{\mathrm{l}}}{\mathrm{x}_{\mathrm{jk}}}\right)\right\} \times 100
$$

It assumes there are two different countries or regions $\mathrm{i}$ and $\mathrm{j}$, this formula estimates export similarity of $\mathrm{i}$ and $\mathrm{j}$ with $\mathrm{k}$. $\mathrm{X}$ stands for export, 1 stands for the certain commodity classification, and the two subscripts stand for export country and export destination respectively. $\mathrm{X}_{\mathrm{ik}}^{\mathrm{l}}$ is the share of commodity $1 \mathrm{in} \mathrm{i's} \mathrm{export} \mathrm{to} \mathrm{k}$. $\mathrm{X}_{\mathrm{jk}}^{\mathrm{l}}$ is the share of commodity $\mathrm{l}$ in $\mathrm{j}$ 's export to $\mathrm{k}$. The number of $\mathrm{S}(0 \leq \mathrm{S} \leq 100)$ is bigger, the competition between two countries is harsher in the third market. If the commodity distribution of i's and j's export is identical, the index will take on a value of 100. If i's and j's export patterns are totally dissimilar, the index will take on a value of zero(Finger and Kreinin).

If the product similarity index to rise over time, it shows that the export structure of the two countries or regions is converging, at the same time, it means that the two countries or regions will become more competitive in the third market (Pomfret, 1981; Pearson, 1979); If this convergence occurs between developing countries and developed countries, then a rise index also reflects the rapid economic growth and industrialization in developing countries (Finger and Kreinin, 1979). If the product similarity index to decline over time, it means that the degree of specialization of the 
two countries in third markets is rising, and the trade relationship between the two countries are complementary.

\section{Data Resource and Explanation}

In this paper, the main data source is the UN COMTRADE database, which is the largest and most authoritative international merchandise trade database in the world. The empirical process uses the export data from the database, which includes the export from China and EU to the world, the US and India.

Commodity classification is according to the standard international trade classification SITC (fourth edition) divided into 10 categories, respectively: 0-food and live animals; 1 -beverages and tobacco; 3-mineral fuels, lubricants and related materials; 4-animal and vegetable oils, fats and waxes; 5-chemicals and related products, n.e.s; 6-manufactured goods classified chiefly by material; 7-machinery and transport equipment; 8-miscellaneous manufactured articles; 9-commodities and transactions not classified elsewhere in the SITC. SITC0-4 are primary products, SITC5-9 are manufactured goods. SITC5 and SITC7 are almost capital or technology intensive manufacture products, and SITC6 and SITC8 are almost labor-intensive manufacture products.

\section{Empirical Analysis}

This article selects the world market, the markets of developed countries, and markets of developing countries as sample to analysis export similarity between China and the EU. Selected the US and Indian market as the target market because the two market are important not only to China but EU and have relatively good representative of their export condition. To arrive at an accuracy study outcome, this paper measures the export similarity index by classifying commodities of China and EU according to SITC.

Table 1 to table 3 respectively measures the export similarity index of China and EU in world market, the US market and Indian market. From the overall degree of export similarity, we can conclude that China and EU have a higher level of ESI beyond 65. This outcome shows that there are many similarities in the export commodities and export structure of China and EU.

First, in the world market (table 1), the level of export similarity index of China and EU is relative high and changes in small scope. On the whole, it has a mild decline during 2007 to 2013. Especially in the field of SITC6 manufactured goods classified chiefly by material and SITC7 machinery and transport equipment, the degree of competition of China and EU present a relatively obvious decline trend. This table reflects the fact that the competition between products from China and EU to the world market is fierce, but the degree of competition shows signs of easing in recent years. The competition of primary products (SITC0-4) is stable, meanwhile, the competition of manufactured goods (SITC5-9) is declining a little and trade complementarity is increasing.

Tab. 1 the export similarity index of China and EU in world market

\begin{tabular}{|l|l|l|l|l|l|l|l|}
\hline & 2007 & 2008 & 2009 & 2010 & 2011 & 2012 & 2013 \\
\hline 0 & 2.520 & 2.290 & 2.713 & 2.608 & 2.660 & 2.542 & 2.523 \\
\hline 1 & 0.114 & 0.107 & 0.137 & 0.121 & 0.120 & 0.126 & 0.118 \\
\hline 2 & 0.747 & 0.791 & 0.679 & 0.735 & 0.789 & 0.700 & 0.659 \\
\hline 3 & 1.711 & 2,221 & 1.696 & 1.691 & 1.700 & 1.514 & 1.529 \\
\hline 4 & 0.025 & 0.040 & 0.026 & 0.023 & 0.028 & 0.027 & 0.026 \\
\hline 5 & 4.946 & 5.546 & 5.164 & 5.550 & 6.046 & 5.543 & 5.415 \\
\hline 6 & 13.543 & 13.549 & 12.021 & 12.513 & 12.030 & 11.531 & 11.351 \\
\hline 7 & 42.485 & 42.882 & 40.006 & 41.834 & 40.269 & 40.290 & 40.545 \\
\hline 8 & 10.312 & 10.382 & 10.283 & 10.238 & 9.700 & 10.062 & 10.346 \\
\hline 9 & 0.179 & 0.120 & 0.136 & 0.093 & 0.123 & 0.069 & 0.078 \\
\hline ESI & 76.583 & 77.927 & 72.861 & 75.404 & 73.465 & 72.404 & 72.591 \\
\hline
\end{tabular}

Source: the UN COMTRADE database 
Second, in the United States market (table 2), the export similarity index of China and EU is rise after fall, a u-shaped glyph. Since 2009, the index begins to rise to the height of 71.339 in 2013, which reflects that the export competition between China and EU in the United States is growing. The competition of SITC6 manufactured goods classified chiefly by material is declining, at the same time, the competition of SITC5 chemicals and related products, SITC7 machinery and transport equipment and SITC8 miscellaneous manufactured articles are going up. This table reflects that the export structure adjustment of the field of manufactured goods in China and EU. The increasing competition of such commodities, just like SITC5 and SITC7 which almost are capital or technology intensive manufactured goods, proves the successful achievement of Chinese export structure upgrade, the larger export scale of capital or technology intense products and the stronger competitive strength.

Tab. 2 the export similarity index of China and EU in the US market

\begin{tabular}{|c|c|c|c|c|c|c|c|}
\hline & 2007 & 2008 & 2009 & 2010 & 2011 & 2012 & 2013 \\
\hline 0 & 1.626 & 1.600 & 1.927 & 1.851 & 1.858 & 1.790 & 1.717 \\
\hline 1 & 0.017 & 0.014 & 0.015 & 0.010 & 0.011 & 0.014 & 0.015 \\
\hline 2 & 0.496 & 0.571 & 0.422 & 0.443 & 0.509 & 0.520 & 0.483 \\
\hline 3 & 0.554 & 0.934 & 0.314 & 0.306 & 0.328 & 0.371 & 0.354 \\
\hline 4 & 0.011 & 0.013 & 0.017 & 0.020 & 0.023 & 0.024 & 0.028 \\
\hline 5 & 2.899 & 3.853 & 3.458 & 3.602 & 4.046 & 3.814 & 3.751 \\
\hline 6 & 11.099 & 10.218 & 8.554 & 9.636 & 10.239 & 10.055 & 9.552 \\
\hline 7 & 41.894 & 40.241 & 38.737 & 39.348 & 40.354 & 41.752 & 42.970 \\
\hline 8 & 11.622 & 10.939 & 11.558 & 11.500 & 11.405 & 11.560 & 12.465 \\
\hline 9 & 0.056 & 0.069 & 0.082 & 0.053 & 0.052 & 0.004 & 0.004 \\
\hline ESI & 70.274 & 68.451 & 65.086 & 66.770 & 68.827 & 69.905 & 71.339 \\
\hline
\end{tabular}

Source: the UN COMTRADE database

Third, in Indian market (table 3), the export similarity index of China and EU presents a significant decline, from 84.550 in 2007 to 77.261 in 2013. The index indicates a tendency of the trade competitiveness reduction and the trade complementary enhancement of the export condition between China and EU in Indian market. The competition in the field of SITC6 manufactured goods classified chiefly by material, SITC7 machinery and transport equipment and SITC9 commodities and transactions not classified elsewhere in the SITC presents downward trend year by year, which proves that the manufactured goods trade between China and EU in Indian market is increasingly complementary and more specialization.

Tab. 3 the export similarity index of China and EU in Indian market

\begin{tabular}{|l|l|l|l|l|l|l|c|}
\hline & 2007 & 2008 & 2009 & 2010 & 2011 & 2012 & 2013 \\
\hline 0 & 0.382 & 0.350 & 0.411 & 0.496 & 0.460 & 0.542 & 0.506 \\
\hline 1 & 0.009 & 0.009 & 0.023 & 0.008 & 0.009 & 0.015 & 0.019 \\
\hline 2 & 1.588 & 1.276 & 1.099 & 1.272 & 1.332 & 1.171 & 1.093 \\
\hline 3 & 0.407 & 0.619 & 0.864 & 0.463 & 0.738 & 0.607 & 0.669 \\
\hline 4 & 0.008 & 0.041 & 0.006 & 0.005 & 0.004 & 0.009 & 0.006 \\
\hline 5 & 8.060 & 9.023 & 10.642 & 10.726 & 9.559 & 11.139 & 11.691 \\
\hline 6 & 24.748 & 21.200 & 17.998 & 20.640 & 20.321 & 19.449 & 19.361 \\
\hline 7 & 44.514 & 44.211 & 43.841 & 40.477 & 37.285 & 38.088 & 36.431 \\
\hline 8 & 4.756 & 5.110 & 6.245 & 7.066 & 6.432 & 7.055 & 7.486 \\
\hline 9 & 0.079 & 0.568 & 0.377 & 0.097 & 0.111 & $0.000^{(1}$ & $0.000^{2}$ \\
\hline ESI & 84.550 & 82.406 & 81.507 & 81.250 & 76.251 & 78.074 & 77.261 \\
\hline
\end{tabular}

$\begin{array}{lll}\text { (1) } 0.0000042 \quad 2) & 0.0000001\end{array}$

Source: the UN COMTRADE database 


\section{Conclusion}

From the analysis above of the data from 2007 to 2013, we can concluded that China and EU have a high degree of the export similarity index and convergent export structure no matter in developed countries' market of developing countries' market. There are two aspects reasons as following.

First, the Central and Eastern Europe countries join the European Union formally in 2004. This enlargement of EU leads to the more similar export similarity index of China and EU, because China and those new member states in EU have a certain degree of similarity of industrial structure. Those make the export trade of China and EU must be competitive.

Second, due to the gradual loss of the comparative advantage of cheap labor in recent years, China is not only taking advantage of low cost labor resources to achieve competitive advantage, but to devote efforts to the optimization and adjustment of economic structure, by shifting the model relying on the export of labor-intensive products to the model relying on the capital-intensive and technology-intensive products. It is this effort that lead the export similarity index of China and EU is high and increasing, and the enhancement of competition.

In the face of this situation, there are mainly several policy suggestions:

First, based on the fact that China and the EU have higher export similarity index and fierce market competition, the two sides should strengthen bilateral coordination and cooperation in foreign trade activities, negotiate to establish mutually beneficial free trade agreement and cooperate instead of compete to reduce the trade friction and vicious competition in the international market between the two sides. China and EU need to avoid the harmful effect of similarity of export commodities and promote bilateral trade and the common development of the national economy.

Second, China should continue to deepen economic system reform and promote economic structure transformation. At present our country is still in the processing and manufacturing link in the global value chain, mainly exports labor-intensive products and difficult to form a comparative advantage of capital-intensive and technology-intensive products, because lack of the competitiveness of capital-intensive and technology-intensive product. China should increase funding support for capital-intensive and technology-intensive industry to improve the capacity of independent innovation, raise product added value and extend to the direction of product development and services link of the value chain, enhance the overall competitiveness of the our country export commodities.

\section{Acknowledgement}

This article is sponsored by Shandong Provincial Science and Technology Development Planning project(2014GGH213001) " Study on the early warning mechanism of agricultural industry damage of Shandong province from the perspective of global value chain" hosted by Wang Peizhi; Shandong Provincial Natural Science Foundation project(ZR2013GM013) "Research on agricultural products trade's marginal measures and upgrading route of Shandong Province" hosted by Wang Peizhi; Shandong Provincial Academy of Social Sciences project(14AWTJ01-15) "Research on early warning system of financial internationalization development in Shandong Province" hosted by Wang Peizhi; Shandong Education Department's Project (sdyy11201) "Research on Innovation of Bilingual Teaching of Graduates in International Business, Shandong University of Finance and Economics" hosted by Liu Xinying; Project (jy201212 )"Research on Combining Chinese Graduates with Foreign Students in Teaching International Economics and Trade in English" hosted by Liu Xinying; Shandong science and Technology Department Project(2014RKB019A6) "Research on agricultural industry security of Shandong province from the perspective of open market" hosted by Liu Xinying. 


\section{Reference}

[1]Cheng Hai-biao, A Research on Export Comparability between China and Five Countries of ASEAN[J].Business Economics and Administration, 2006(3):37-41.

[2]Fan Ai-jun and Chang Li-li, Competition and Complementary between the Sino-US hi-tech products export An Empirical Analysis with Export Similarity Index [J].World Economy Study, 2010(4):39-43.

[3]J.M. Finger, M.E. Kreinin. A measure of ' Export Similarity' and Its Possible Uses[J]. The Economic Journal, 1979(89): 905-912.

[4]Mitchell Kellman and Tim Schroder, The Export Similarity Index: Some Structural Tests[J]. The Economic Journal, 1983(93): 193-198.

[5]Shi Zhi-yu, Export Similarity and Trade Competition: A Comparative Study on China and ASEAN Countries [J].Finance \& Economics, 2003(9): 53-57.

[6]Sun Lin, The Relationship of Agriculture Trade Competition between China and ASEAN [J].Journal of International Trade, 2005(11): 71-76.

[7]Sun Lin, Study on the Agricultural Trade Competition between China and Japan \& Korea-Empirical Analysis with Export Similarity Index [J]. Journal of International Trade, 2008(10):53-56.

[8]Wang Guo-an and Wang Ya-wen, An Empirical Study on Comparative Advantage and the Export Similarity of Manufactured Products between China and South Korea [J]. Journal Of Business Economics, 2007(6):51-56.

[9]Xu Xin-peng and Song Li-gang, Export Similarity and Model of Asian Development [J]. World Economic Papers, 2002(5):3-15.

[10]Yan Chun-rong and Zhang Qiu-ju, Empirical Study on the Trade Complementation and Competence between China and EU [J]. Finance and Trade Research, 2010(2):40-45.

[11]Xie Rui and Xiao Hao, Study on the Similarity of Export Structure between China and ASEAN Based on Technical Classification [J]. International Economics and Trade Research, 2013(1):80-89.

[12]Tang Yi-hong and Wang Ming-rong, FDI, Export Similarity and Optimization of China's Export Commodity Structure [J]. International Economics and Trade Research, 2010(4):34-41.

[13]Yang Jie and Shan Wen-ting, Comparisons of Characteristics and Factors between China-EU Trade and China-ASEAN Trade-Based on Gravity Model [J]. Journal of International Trade, 2007(11):21-24. 